\title{
NILAI-NILAI KETELADANAN GURU DALAM INTERAKSI PEMBENTUKAN KARAKTER ANAK (PAUD)
}

\author{
Rokhyanto ${ }^{1)}$, Umi Salamah ${ }^{2)}$ \\ IKIP Budi Utomo \\ rokhyanto3@gmail.com*, umi.salamah@budiutomomalang.ac.id
}

\begin{abstract}
Departing from the various realities as described above, the implementer of this service wishes to examine the importance of the exemplary educators in shaping the character of children. This dedication will begin with the basic concept of modeling, then end with the importance of modeling for the teacher in shaping the personalities (characters) of children towards independence. The role of parents is very important, especially to catch the concrete rather than the abstract. As a second parent, the teacher might find it easy to communicate his message verbally. However, children will find it difficult to understand the message if they see that their education does not provide an example of the message it conveys. Advances in technology also have an impact on children's behavior along with the progress of science and technology. This gives a very big impact on the behavior of students who increasingly leads to negative things. Children's behavior patterns tend to deviate from the corridors of noble morals. Based on the range of exemplary values in the interaction of character building namely: efforts to ask for parental support, not getting bored giving directions, cooperation of all parties. The factors supporting the exemplary methods in PAUD, teachers, teaching materials, the local environment and schools, technological progress.
\end{abstract}

Keywords: Values; role models; interactions; characters

Submit
9 Juli 2020
Diterima Juli 2020

Dipublikasikan
31 Juli 2020

DOI : https://doi.org/10.33503/pambudi.v4i01.850

\section{ANALISIS SITUASI}

Pembelajaran di kelas perlu tingkah laku seorang guru yang mencerminkan perilaku yang benar-benar bisa dicontoh oleh anak kecil. Hampir setiap hari anak melihat sosok guru yang membimbing dan mengajari segala hal di sekolah, sehingga dalam ingatan anak terpatri segala gerak-gerik guru yang menjadi panutan untuk anak-anak. Usaha ini tidak saja membebankan kepada guru-guru di sekolah, tetapi harus ada campur tangan dari berbagai pihak baik pemerintah, sekolah, dan keluarga. Hal ini untuk membuat hubungan yang terkadang kurang memahami makna hubungan itu. Berkaitan dengan pembentukan karakakter anak, yang notabene mencontoh kepada sosok guru sebagai perilaku keteladanan akan dikatakan berhasil, jika lingkup pendidikan ada kesinambungan dan keharmonisasi antara pemerintah, sekolah, dan keluarga. Saling menyadari antara keluarga dan pemerintah sebagai bengkel pembentukan karakter yang harus lebih diberdayakan, sedangkan keluarga dan sekolah secara langsung pembentuk karakter anak dengan melihat guru berperilaku di depan kelas.

Fenomena ini bisa jadi akan menurunkan citra perilaku anak yang mandek, jika control orangtua secara kontinuitas tidak dilakukan. Akan tetapi, justru sebaliknya jika guru yang di sekolah sudah berperilaku baik dan pengawasan orangtua di rumah sangat baik tidak menutup kemungkinan akan menghasilkan perilaku anak yang baik pula. Sejak dini guru selalu mengajarkan perilaku yang baik kepada anak sebagai modal dasar untuk meneruskan nilainilai kebangsaan pada generasi yang akan 
datang. Bila hal itu dijaga dan dikawal dengan baik, maka tidak ada kata yang buruk "bangsa yang rapuh dan bangsa yang tidak jujur." Untuk selanjutnya, yang ditemukan pada masyarakat berkaitan dengan penanaman keteladanan dari guru kepada anak, akan menghasilkan sebuah perilaku yang jujur, sopan, agamis, sumeh, grapyak, dan lain-lain.

Solusi yang diinginkan tentu saja sebisa mungkin dapat membenahi hal-hal yang belum benar menjadi lebih benar atau lebih baik. Pokok dari keteladanan guru di kelas sebuah pembelajaran yang berkelanjutan yang dilihat oleh anak. Tentu saja pembelajaran yang tidak hanya melulu di dalam kelas. Agar tidak bosan dan terkadang perlu juga pembelajaran di luar kelas biar anak-anak senang dan gembira.

Pembelajaran dapat berlangsung secara alamiah melalui pemaknaan pribadi terhadap pengalaman dalam menjalani kehidupan. Baik pengalaman yang happy maupun tidak happy, semuanya dapat menjadi proses pembelajaran untuk membangun karakterkehidupan. Sosok guru adalah pihak yang berhubungan langsung dengan anak dalam pelaksanaan di kelas, maka guru merupakan terdepan dari program pembelajaran bahkan tata nilai, sikap dan perilaku yang berdampak pada menipisnya sendi-sendi moral dan akhlak anak bangsa yang berimbas pada buramnyaa karakter anak. Membangun keteladanan sangat penting, yang ditanamkan oleh para pendiri pendidikan; semakin lama semakin menipis dari memudarnya keteladanan para tokoh, orangtua, dan bahkan guru sebagai pengemban utama pendidikan formal di sekolah. Kenyataan, buramnya nilai-nilai keteladanan guru dapat ditunjukkan dengan hasil temuan KPAI bahwa kekerasan terhadap anak yang dilakukan oleh tenaga guru menunjukkan hasil yang cenrung semakin tinggi dari waktu ke waktu.

Kekerasan ini meliputi tindakan menempeleng, mencubit, menjambuk, menjewer, memukul dengan penggaris. Kekerasan ini terkadang guru berteriak-teriak agar anak-anak takut. kekerasan yang berkaitan dengan semua itu tidak ada gunanya sama sekali, karena guru seorang pendidik atau orangtua kedua yang diamanati para orangtua atau wali siswa atau wali anak. Caracara itu kurang disiplin bagi guru dan tidak pantas, beluma adanya keterpanggilan jiwa pendidik, bila hal itu ada sosok guru yang seperti itu lebih baik dia dikeluarkan dari sekolah.

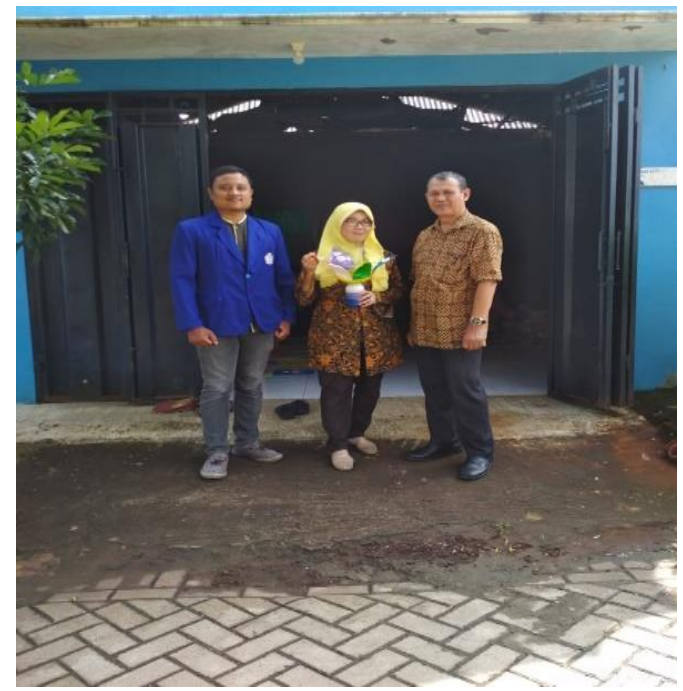

Gambar 1. Sebelum pembelajaran di PAUD, foto bersama sambil menunjukkan media Bola Berkembang

Dari berbagai realitas seperti telah dijabarkan di atas, pelaksana ingin mengkaji pentingnya keteladanan pendidik dalam pembentukan karakter anak. Pengabdian ini akan dimulai dengan konsep dasar keteladanan, lalu diakhiri dengan pentingnya keteladanan bagi guru dalam membentuk kepribadian (karakter) anak. Mengacu pada analisis situasi dan hasil diskusi bersama mitra mengenai kendala dan permasalahan mitra tentang para guru untuk menjadi orangtua kedua, yakni: di PAUD Ar-Rifqoh ini dapat dirinci sebagai berikut:

01) faktor guru belum biasa memberi salam kepada anak, ketika mereka diantar para orangtua,

02) faktor guru belum siap sepenuhnya menerima anak ketika masuk ke ruangan, 
03) faktor guru keluar-masuk ke ruangn kelas sambil merapikan barang-barang yang ada di meja,

04) faktor guru terkesan belum siap jika pagi hari menerima hantaran anak didiknya ketika di antar para orangtua.

Demikianlah berbagai macam kendala dan hambatan yang ada dalam proses belajar. Kiranya perlu pendampingan untuk memberikan pencerahan yang diberikan kepada guru sebagai model keteladanan langsung yang akan dilihat dan ditiru oleh anak didik setiap hari. Maka dari itu, usahakan jangan sampai membuat anak didik mempunyai kelas yang kurang baik kepada gurunya.

Adapun kendala dan hambatan dalam penerapan menggunakan nilai-nilai keteladanan; perlu diketahui lebih dahulu upaya-upaya para guru dalam penerapan nilainilai keteladanan; mengetahui dan memahami faktor-faktor pendukung dan penghambat pelaksanaan implementasi nilainilai keteladanan dalam interaksi proses belajar; dan mengetahui implementasi nilainilai keteladanan dalam interaksi belajar mengajar di paud. Semua itu untuk memperoleh deskriptif objektif tentang nilainilai keteladanan para guru dalam berinteraksi dan teraplikasi bagi anak PAUD Ar-Rifqoh dalam pembentukan karakter anak di lingkungan tempat mereka mencari ilmu dalam lingkungan yang baik. Selanjutnya, hal ini bertujuan memperoleh deskriptif tentang membangun nilai-nilai keteladanan dan bentuk-bentuk keteladanan dalam interaksi belajar mengajar.

Sehubungan dengan permasalahan yang dihadapi oleh pembelajaran Pendidikan Anak Usia Dini (PAUD) Ar-Rifqoh di Perumahan Gardenia Blok K-10 Kecamatan Pakis, Kabupaten Malang, kami pelaksana pengabdian akan membantu memberikan sumbang saran yang bernilai pendidikan edukasi kepada guru-guru agar bermanfaat untuk anak didiknya agar di dalam kelas lebih ngerasan, oleh karena ada media-media pembelajaran edukasi tersebut. Di antara di dalam kelas perlu ada hiasan yang bernilai edukasi tersebut, yaitu:

1) Sikap guru selalu baik dan sayang kepada anak didiknya.

2) Area dinding di ruang belajar perlu ditempeli media pembelajaran berupa gambar buah-buahan.

3) Area dinding di ruang belajar perlu ditempeli gambar guru sedang berjabat tangan dengan anak paud,

4) Area dinding di ruang belajar perlu ditempeli gambar guru dengan dibantu anak sedang mengangkat bak sampah yang penuh,

5) Area dinding di ruang belajar perlu ditempel gambar guru sedang memberi makan hewan,



Gambar 2. Anak-anak PAUD dilatih sambil menepuk tangan 3 kali

\section{Solusi dan Target Luaran}

Solusi untuk pembelajaran berkaitan dengan model yang diterapkan di dalam kelas untuk anak PAUD biasanya menggunakan model kelompok dan dalam satu kelas biasanya dibagi menjadi empat kelompok. Model kelompok ini biasanya menggunakan meja melingkar atau meja-meja kecil yang didekatkan agar anak leluasa menaruk barangbarang permainannya. Dengan pembelajaran model kelompok, permainan yang mengarah pada gambar-gambar guru berbuat baik kepada sesame, hewan, agar mengembangkan berbagai aspek perkembangan anak, seperti fisik motorik, bahasa, kecerdasan, dan sosialisasi. Selain itu, perilaku dan gambar-gambar orang berbuat 
baik yang dijelaskan oleh guru agar dapat memahami arti dari gambar tersebut.

Target capaian yang ingin dicapai dalam kegiatan pengabdian kepada masyarakat dengan rencana target capaian luaran dengan judul: membiasakan hidup disiplin diri bagi guru, mempersiapkan bahan ajar untuk anak atau membuat $\mathrm{RKH}$, berangkat ke tempat kerja sebelum anak-anak tiba di sekolah agar keteladanan ini selalu tertjaga dengan baik. Adapun wujud luaran berupa tulisan di dalam jurnal dan luaran saran dan nasihat kepada mitra pengabdian yakni: rumah PAUD ArRifqoh Perumahan Gardenia Blok K-10, Desa Saptorenggo, Pakis Malang.

\section{METODE PELAKSANAAN}

\section{Jenis Pengabdian Masyarakat}

Jenis pengabdian masyarakat ini merupakan kegiatan berbentuk program kemitraan masyarakat yakni program pengabdian yang murni pembelajaran atau solusi pembelajaran bagi guru-guru di sekolah. Selain itu, model pembelahran di kelas termasuk yang diterapkan di dalam kelas untuk anak paud biasanya menggunakan model kelompok dan dalam satu kelas biasanya dibagi menjadi empat kelompok. Model kelompok ini biasanya menggunakan meja melingkar atau meja-meja kecil yang didekatkan agar anak leluasa menaruk barang-barang permainyannya.

Misalnya pembelajaran model kelompok, permainan yang mengarah pada gambar dan hewan seorang guru harus memberi penjelasan kepada anak agar dapat memahami sosok hewan dan gambar. Guru harus memberikan ciri -ciri hewan atau gamabar yang ada dihadapanya. Metode yang diaplikasikan pada anak usia dini ini melalui tahap-tahap ini mengacu kepada awal-awal tingkatan memahami sebuah gambar sebagai alat peraga edukasi lalu apa maksud dari gambar yang berisi tersebut untuk memberikan atau menyerap makna gambar alat peraga kepada anak kecil. Jadi, dengan tahap-tahap ini anak digiring secara dini agar bisa memahami atau terbiasa dengan pembelajaran secara nyata lewat perilaku guru dan gambar dengan mengamati gambar yang bermacam ragam wujud dan bentuknya.

Berdasarkan penjelasan di atas bias diambil kesimpulan bahwa metode belajar sambil bermain, yaitu: guru bercerita dan menjelaskan alat peraga yang ditunjukkan kepada anak didik, agar mereka merasa senang, sehingga daya ingat mereka semakin kuat.

Metode peningkatan mutu pembelajaran sangat penting untuk selalu menuju kemajuan yakni: pembelajaran harus ditempatkan sebagai sasaran utama dari semua program pengembangan dan investasi yang dilakukan oleh sekolah PAUD. Pencapaian fokus pengembangan ini tidak dapat dilakukan berdiri sendiri, tetapi melibatkan upaya-upaya yang bersifat parsial. Oleh karena itu, tercapainya mutu pembelajaran harus dilihat sebagai hasil akhir dari upaya peningkatan mutu banyak faktor: peningkatan mutu pendidik PAUD dan peningkatan link bahan ajar ke anak didik.

\section{Waktu, Tempat, dan Sasan Pengabdian}

Kegiatan pengabdian kepada masyarakat ini titik tolaknya pada perilaku guru-guru yang ada di paud Ar-rifqoh di lingkungan perumahan Gardenia K-10, Pakis, Malang, kegiatan pengabdian ini dilaksanakan pada tanggal 01 Januari-30 Juni 2020. Selama 6 bulan itu kami tidak secara terus-menerus berada di paud ArRifqoh, tetapi kami hanya masuk 3 kali dalam seminggu membantu para guru.

\section{Prosedur dan Instrumen Pengabdian}

Program pengabdian kepada masyarakat ini berlangsung sesuai dengan rencana dan terarah dengan langkah-langkah sebelumnya melalui abservasi lebih dahulu, lalu kami diskusi, mengambil kesepakatan, dan baru kami terjun ke sekolah paud. Adapun langkah-langkah pelaksanaan pengabdian kepada masayarakat sebagai berikut: 
1) Analisis situasi menentukan sasaran dan bidang permasalahan yang akan dianaklisis. Kegiatan pengabdian kepada masayarakat ini difokuskan pada perilaku guru-guru agar dapat dituru oleh anak didik selama dapat ditiru oleh anak didik selama mereka belajar di situ.

2) Identifikasi masalah, dengan melakukan analisis situasi tentang sasaran menjadi dasar dilakukannya pemetaan masalah agar lebih khusus.

3) Menentukan tujuan secara khusus yang ingin dicapai dalam kegiatan pengabdian kepada masyarakat apa yang ingin dihasilkan atau perubahan apa yang dikehendaki.

4) Masih dalam menentukan tujuan atau jabaran pemecahan masalah melalui perilaku guru bercerita dan menjelaskan alat peraga yang ditujukkan kepada anak didik, agar mereka merasa senang, sehingga daya ingat mereka semakin kuat. Peningkatan mutu pembelajaran ini harus ditempatkan sebagai sasaran utama dari semua program pengembangan yang dilakukan di paud. Pencapaian focus pengembangan tidak dapat dilakukan berdiri sendiri ada upaya-upaya yang bersifat parsial.

5) Evaluasi kegiatan dan hasil totalitas pelaksanaan sebagai identitas masalah yang dimonitoring lalu dinilai setiap bulan agar hasilnya menjadi baik.

Instrumen yang digunakan dalam pelaksanaan kegiatan pengabdian kepada masyarakat berupa lembar kerja yang dilengkapi catatan kemajuan pada perilaku guru dalam proses belajar-mengajar agar beroleh gambaran yang jelas selama pelaksanaan pengabdian.

\section{HASIL DAN PEMBAHASAN}

\section{Gambaran Umum Geografis Lokasi Pengabdian Masyarakat}

Banyak PAUD di lingkungan Desa Saptorenggo, di antara Paud yang ada di Perumahan yakni PAUD Ar-rifqoh yang berada di Gardenia Blok K-10. Tepatnya di Perumahan Gardenia, Pakis, Malang. Wilayah Pakis ini ini terletak pada ketinggian antara 441 - 668 meter di atas permukaan air laut. Letaknya yang berada di tengah wilayah Kabupaten Malang terletak $112,06^{\circ}-112,06^{\circ}$ Bujur Timur dan $7,05^{\circ}-8,01^{\circ}$ Lintang Selatan, dengan di kelilingi gunung. Sebelah utara ada gunung Arjuno, sebelah timur ada gunung Semeru, sebelah barat ada gunung Kawi, dan sebelah utara ada gunung Kelud.

\section{Karakteristik Sasaran Pengabdian Masyarakat}

Karakteristik sasaran yang ikut serta dalam pelaksanaan pengabdian, meliputi: usia dan pendidikan para guru dan jumlah guru yang ada di PAUD Ar-Rifqoh di lingkungan Perumahan Gardenia, Pakis Malang.

Peningkatan mutu Pembelajaran tentang keteladanan dilaksanakan pagi hari dan sebelum anak-anak belajar, mereka bermain lebih dahulu dengan barang-barang (property) yang ada di rumah PAUD, sehingga anak-anak tidak terkesan tidak selalu pembelajaran formal, tetapi anak-anak lebih bahagia. Selain itu, anak-anak juga satu kali dalam seminggu dan di depan rumah berolah raga dengan menirukan senam ringan yang dipandu oleh guru.

Selama proses belajar-mengajar di dalam ruang kelas, hal yang ingin dikehendaki berkaitan dengan peningkatan, yakni:

1) Mutu guru PAUD untuk keteladanan

2) Akses dan mutu siswa baru

3) Mutu sarana pembelajaran baik yang bersifat praktek.

4) Mutu layanan administrasi, data dan informasi anak.

5) Mutu bahan ajar dan praktikum bagi anak PAUD.

6) Mutu RKH disesuaikan dengan kebutuhan pengguna lulusan atau perkembangan ilmu, teknologi, dan seni (sesederhana mungkin).

7) Mutu kegiatan anak dalam bidang inovasi dan kreativitas. 
8) Mutu kegiatan anak bersosialisasi dengan teman yang lain.

Tabel 1. Data Pendidikan Guru

\begin{tabular}{|l|l|l|}
\hline No. & \multicolumn{1}{|c|}{ Nama guru } & \multicolumn{1}{c|}{ pendidikan } \\
\hline 1. & Bu Zaki & $\mathrm{D}-3$ \\
\hline 2. & Bu Sulamening & $\mathrm{S}-1$ \\
\hline 3. & Bu Tri & SLTA \\
\hline
\end{tabular}

Tabel 2. Data indikator Pelaksanaan Pembelajaran

\begin{tabular}{|c|c|c|}
\hline Nama guru & Indikator & Skor \\
\hline \multirow[t]{5}{*}{ Bu Zaki } & $\begin{array}{l}\text { Membuka dan menutup } \\
\text { pelajaran }\end{array}$ & 7 \\
\hline & Penanganan anak & 7 \\
\hline & Kepeduliah rasa ibu & 8 \\
\hline & Bersikap kepada anak & 7 \\
\hline & $\begin{array}{ll}\begin{array}{l}\text { Kebersihan } \\
\text { pembelajaran }\end{array} & \text { selesai } \\
\end{array}$ & 8 \\
\hline \multirow[t]{5}{*}{$\begin{array}{l}\mathrm{Bu} \\
\text { Sulamening } \\
\end{array}$} & $\begin{array}{l}\text { Membuka dan menutup } \\
\text { pelajaran }\end{array}$ & 8 \\
\hline & Penanganan anak & 8 \\
\hline & Kepeduliah rasa ibu & 8 \\
\hline & Bersikap kepada anak & 8 \\
\hline & $\begin{array}{ll}\text { Kebersihan } & \text { selesai } \\
\text { pembelajaran } & \\
\end{array}$ & 8 \\
\hline \multirow[t]{5}{*}{ Bu Tri } & $\begin{array}{l}\text { Membuka dan menutup } \\
\text { pelajaran }\end{array}$ & 6 \\
\hline & Penanganan anak & 6 \\
\hline & Kepeduliah rasa ibu & 6 \\
\hline & Bersikap kepada anak & 6 \\
\hline & $\begin{array}{ll}\text { Kebersihan } & \text { selesai } \\
\text { pembelajaran } & \end{array}$ & 8 \\
\hline
\end{tabular}

\section{Peningkatan Mutu lulusan PAUD}

Peningkatan mutu Hasil akhir anak paud dari program peningkatan mutu pembelajaran harus dapat diukur dengan berbagai indikator kinerja, karena anak paud dikatakan lulus dengan baik tentu saja berkat keteladanan dan kepintaran guru, misalnya :

1) Peningkatan nilai anak-anak

2) Peningkatan nilai lulusan, baik untuk pelajaran melukis, angka atau membaca

3) Peningkatan jumlah anak yang pintar dalam melukis atau berhitung dengan cepat

4) Peningkatan pengakuan pengguna lulusan terhadap lulusan untuk melanjutkan ke SDN, MI atau ke pondok pesantren.

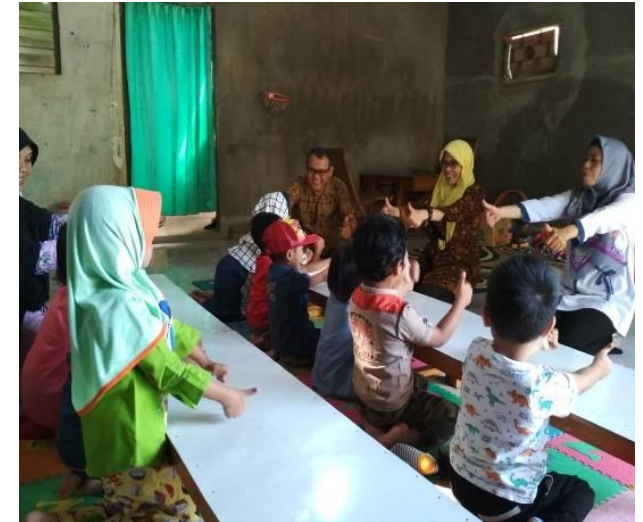

Gambar 3. Proses pembelajaran berlangsung dengan antusias anak PAUD

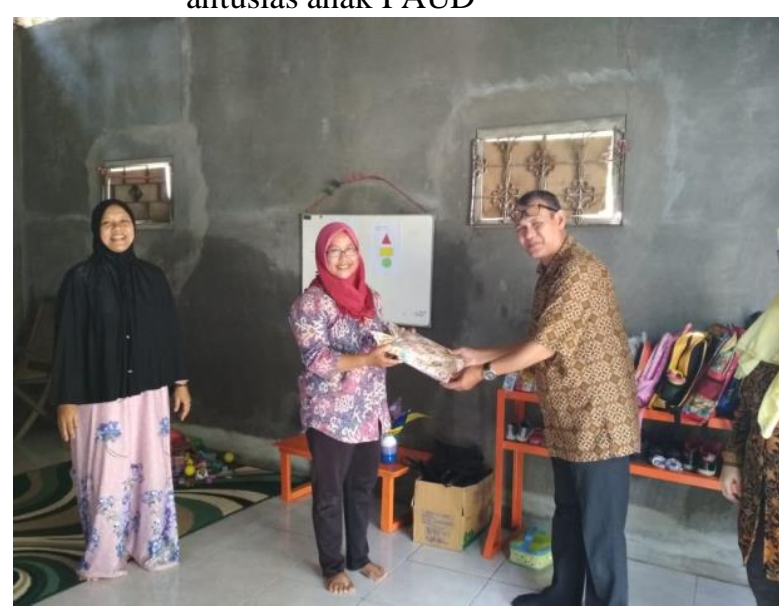

Gambar 4. Pak Rokhyanto sedang memberi tali asih kepada Guru Paud Ar-rifqoh

\section{KESIMPULAN}

Berdasarkan hasil pengabdian ini dan pembahasannya dapat disimpulkan sebagai berikut:

1. Sasaran pengabdian kepada masayarakat yang ditujuan kepada para guru ini ratarata pada usia 40-an dan memiliki pendidikan yang tidak linear PAUD, ada lulusan S-1, D-3, dan SLTA.

2. Para guru jika mengajar di ruang kelas, selalu berpedoman pada rencana kegiatan harian (RKH) seperti RPP begitu yang disesuaikan dengan silabusnya kegiatan anak-anak

3. Sasaran keteladanan guru, harus membiasakan anak untuk menggunakan bahasa yang baik dan sopan, berjabat tangan, salam dengan guru sebelum dan sesudah proses belajar mengajar. Dari penerapan bentuk-bentuk keteladanan ini, anak memiliki kebiasaan yang baik, 
sehingga secara otomatis anak memiliki karakter dan akhlak yang baik.

4. Sasaran keteladanan guru, selalu berupaya a yang dilakukan dalam mengatasi hambatan dalam proses belajar mengajar di paud yakni: dengan cara meminta dukungan orang tua, bekerja sama dengan seluruh pihak sekolah dan selalu memberikan pengarahan anak yang diwujudkan dalam tata tertib sekolah.

5. Sasaran keteladanan guru, Faktor pendukung pelaksanan metode keteladanan dalam proses belajar mengajar di paud yakni: orang tua, guru, dan lingkungan. Orang tua memberikan manfaat yang cukup besar dalam mendukung pelaksanaan metode keteladanan baik di rumah maupun di sekolah. Orang tua memiliki andil yang cukup besar dalam pembentukan kepribadian anak di lingkungan keluarga, sedangkan faktor penghambat pelaksanaan metode keteladanan dalam proses belajar mengajar di paud yakni: lingkungan dan adanya kemajuan teknologi yang pesat. Kemajuan teknologi membuat generasi penerus bangsa memiliki khasanan keilmuan yang menakjubkan, tetapi disisi lain, akhlak mereka mengalami penurunan yang sangat drastis. Dulu anak memiliki tingkat kesopanan yang tinggi, dibandingkan anak sekarang

\section{Saran-saran}

Dalam kegiatan pengabdian kepada masyarakat ini disarankan kepada para guru, yakni:

1. Lebih banyak membuat program keteladanan, karena melihat begitu pentingnya pendidikan keteladanan bagi anak.

2. Membuat program-program Islami, seperti cara-cara sholat dan program guru mendongeng tentang hewan dan para nabi setiap satu minggu sekali.

3. Memberikan tambahan pelajaran, seperti Belajar Tartil Qur'an kepada para anak.
4. Sebelum memulai pelajaran di wajibkan untuk membaca ayat-ayat Al-Qur'an dan bacaan tambahan yang lain seperti Asmaul Husna, agar rasa cinta anak kepada Allah dan Nabi.

\section{DAFTAR PUSTAKA}

Aly, Hery Noer. 1999. Ilmu Pendidikan Islam. Jakarta: Logos Wacana Ilmu.

Al-Nawawi, Imam. 1376 H. Shahih Muslim Syarahat Al-Kamilu lin-Nawawi. Diobend: Yasurnadin Ind Comparic Diobend.

Arief, Armai. 2002. Pengantar Ilmu dan Metodologi Pendidikan. Jakarta: Ciputat Pers

Armai Arief. 2002. Pengantar Ilmu dan Metodologi Pendidikan Islam. Jakarta : Ciputat Pers.

A. R. Muhammad. 2003. Pendidikan di Alaf. Jogjakarta: Prima Sophie

Assegaf, Abdur Rahman. 2007. Pendidikan Islam di Indonesia. Yogyakarta: SUKA Press

Djamarah, Syaiful Bahri dan Aswan Zain. 2006. Strategi Belajar Mengajar. Jakarta: PT Rineka Cipta

Imam Al-Nawawi, Shahih Muslim Syarahat alKamilu Lin-Nawawi, (Diobend: Yasurnadin Ind Companic, Diobend, 1376 H), hlm. 332

Najati, Muhammad Ustman. 2004. Psikologi dalam Perspektif hadits, Terjemahan Zainuddin Abu Bakar, Al-hadits Wa'Ulum Al-Nafs. Jakarta: Pustska Al-Husna

Quthb, Muhammad. 1993. Sistem Pendidikan Islam. Bandung: PT AL-Ma'arif

Ramayulis. 2002. Ilmu Pendidikan Islam. Jakarta: Kalam Mulia

Muhammad Quthb, Sistem Pendidikan Islam, (Bandung: PT. Al-Ma'arif, 1993), cet. ke-3, hlm. 325-332

Muhammad Utsman Najati, Psikologi dalam Perspektif Hadits terjemahan Zainuddin Abu Bakar Al Hadits wa'ulum al-Nafs, (Jakarta: Pustaka al-Husna Baru, 2004), hlm. 167 
Departemen Pendidikan dan Kebudayaan, Kamus Besar Bahasa Indonesia, (Jakarta: Balai Pustaka, 1998), hlm. 466

Armai Arief, Pengantar Ilmu dan Metodologi Pendidikan Islam, (Jakarta: Ciputat Pers, 2002, cet. ke-2, hlm. 117

Hery Noer Aly, Ilmu Pendidikan Islam, (Jakarta: Logos Wacana Ilmu, 1999), cet. ke-2, hlm. 178-180

Ahmad Tafsir, Ilmu Pendidikan dalam Perspektif Islam, (Bandung: PT. Remaja Rosdakarya, 1994), cet. ke-2, hlm. 46

Jakarta: Jakarta Pers, 2 002. Azra, Azyumardi, Kita Sulit Menemukan Keteladanan, Republika Newsroom, Jumat,28 November 2008 dan dapat diakses dari http://webcache.googleusercontent.com/se arch?q=cache:WBTTndxeK2gJ:koran.repu blika.co.id/berita/17112+definisi+ketelada nan\%3F \&cd=7\&hl=id\&ct=clnk\&gl=id Dw iastuti, Nur,

Arief, Armai. 2002. Pengantar Ilmu dan Metodologi Pendidikan Islam. Jakarta: Ciputat Press. 